\title{
From blight to beauty: the controversial creation of the first U.S. industrial-heritage park
}

\section{Tanya Whitehouse}

(Riverland Community College)

\begin{abstract}
This paper describes and assesses Richard Haag's controversial campaign to create Seattle's Gas Works Park. Haag's plan is significant in the history of environmental aesthetics, because it was the first to preserve remnants of industrial heritage in a United States city park, and because Haag appealed to aesthetics when making his case. I argue Haag's campaign was persuasive, and I claim the former gas works now function within the park in much the same way as the ruins of parks of previous centuries. And because the structures are now ruins, they do not sanctify the destructive function they used to have. Finally, I claim that human intervention in abandoned, derelict, or post-industrial sites can be worthwhile if it successfully conveys a change in use or function of those sites, thus bringing beauty out of blight.
\end{abstract}

Key words

environmental aesthetics, Gas Works Park, post-industrial landscape, ruins

Gas Works Park in Seattle, Washington is one of the most influential United States parks of the last 100 years. It combines the remnants of rusting gas-works ruins with green spaces (designed in part to alleviate toxic damage) and a view of downtown Seattle along with its' iconic Space Needle. The former gas plant operated at the edge of the city's Lake Union. After it closed and city officials decided to convert the site to a park, they eventually handed the project to renowned landscape architect Richard Haag. Haag's design was unusual in that it proposed preservingsome of the gas-works structures, including its prominent cracking towers.

The park stimulated an international conversation about design and reclamation that continues to this day, and it has served as a model for other major urban 
projects. ${ }^{1}$ Haag won widespread acclaim for his work. ${ }^{2}$ Much has been said about the fine example the park sets in attempting to rehabilitate an environmentally damaged location. But I wish to focus on Haag's aesthetic inspirations. When he surveyed the damaged gas-plant site, Haag became attracted to the ruins of the plant and directed a series of public arguments to the city of Seattle in which he claimed that the structures had aesthetic value and should be preserved. As Haag later recollected, "Gas Works Park is my magnum opus. It was a game-changer. Before that, industrial ruins were considered to be ugly... I began to see the ruins as ghostly groves that lent scale and gave a sense of place. I decided I'd go down to the wire to save those towers. It was very controversial" (Easton 2015). He has pointed out that for some people, it still is. Though the structures are beloved by many who celebrate Haag's imagination, other critics have been puzzled or disgusted by them and think they should be replaced with more conventionally attractive, "park-like" plants and landscaping.

Haag's campaign marks a significant development in the history of environmental aesthetics, because it was the first major campaign to protect and preserve remnants of industrial heritage in a United States city park. It also demonstrated, in a public forum, that industrial ruins can be regarded as aesthetic objects and can valuably contribute to park design. Judgments about the park plan are similarly important, for they mark the conflicted reactions such a plan may cause. As Haag notes, the park design was controversial. The conflict is reflected in the title of a local article: “Gas plant towers: Since when has junk been pretty?” (Welch 1972). The plans for this park, and responses to them, reveal normative assumptions about what a park should be and the kind of aesthetic appeal it should have.

In this paper, I will explain how this famous park came to be and provide some context for the debate its design prompted, drawing on newspaper articles in which the controversy unfolded. I will assess two of Haag's accomplishments: (1) the comparison Haag drew between artistic and architectural objects and the gas works structures, and (2) his encouragement of certain uses of these structures in the

1 The Gas Works Park Partial Bibliography compiled by Richard Haag Associates notes "it is the first park honoring industrial preservation” (Richard Haag Associates 2016). In an interview with the American Society of Landscape Architects, Thaïsa Way says: "[Gas Works Park] changed the way we saw our toxic urban sites. Before Gas Works, we took toxic soil and dumped it into some poor neighborhood's landfill. After Gas Works Park, we decided we had to deal with it on site. We had to keep the memory of previous historical decisions in the landscape, such as industry, even if we may not love that history. That opened up the door to the way we deal with cities today. The way we think about cities and infrastructure today is a legacy of Gas Works. It's critically important, even internationally" (Interview with ThaïsaWay, n.d.). She writes, "it inspired projects across the nation and around the globe, from the work of Julie Bargman in Vintondale, Pennsylvania, to the work of Peter and Annelise Latz at Duisborg Nord, Germany" (Way 2015, 147-148) - though Arthur Lubow reports Latz has said he was unaware of Gas Works Park when working on Landschaftspark Duisborg-Nord (Lubow 2004).

2 In its description of Way's book, the University of Washington Press notes “Gas Works Park is studied in every survey of twentieth-century landscape architecture as a modern work that challenged the tenets of modernism by engaging a toxic site and celebrating an industrial past" (University of Washington Press, n.d.). 
proposed park. Then (3) I briefly consider our concept, "park," and the assumptions about parks that became apparent during the conversations in Seattle, as well as how we should re-purpose abandoned, derelict, or post-industrial sites, such as the former gas plant. I claim that the gas-works structures do lend themselves to aesthetic interest (a fact that may be obscured by their original functions), as Haag argued, and the ideas underlying the design of Gas Works Park actually belong within a long-established tradition of park design. I also explain how the park has avoided becoming a monument to the pollution it once caused. Then I claim that human intervention in abandoned, derelict, or post-industrial sites can be worthwhile if it successfully conveys a change in use or function of those sites and brings beauty out of blight, as one of Seattle's residents said. Haag's Gas Works Park is a good example of this approach.

Crucial to all of these claims is the fact that the park contains industrial ruins, and these ruins, like many others, evince aesthetic reflection, lend themselves to new uses, and have been popular features of our parks and designed landscapes. Because the structures are now ruins, not active gas works, they do not sanctify the destructive function they used to have.

\section{The gas works plant}

The gas works looming aside Lake Union were the first of their kind built west of the Mississippi; their remnants are the last still standing in the United States (Way 2013). The plant was built on a pocket of land along Lake Union that Native Americans considered sacred and Frederick Law Olmsted had admired for its park potential. During their working heyday producing gas for Seattle, the plant's towers jutted starkly above a site growing toxic and filthy, and as Paul Dorpat (2006) describes, "during the plant's coal years, its emissions applied a rose-colored filter to Wallingford sunsets." It closed in 1956, when new technologies rendered it obsolete. At that time, city officials determined it should be converted to parkland. Craig Campbell writes that after its closure, it became "a ghostly reminder of an earlier era which has attracted scores of artists, photographers, and others who found the 'ruins' visually exciting... To most other people, however, the gas plant is merely an ugly eyesore" (Campbell 1973, 340). 

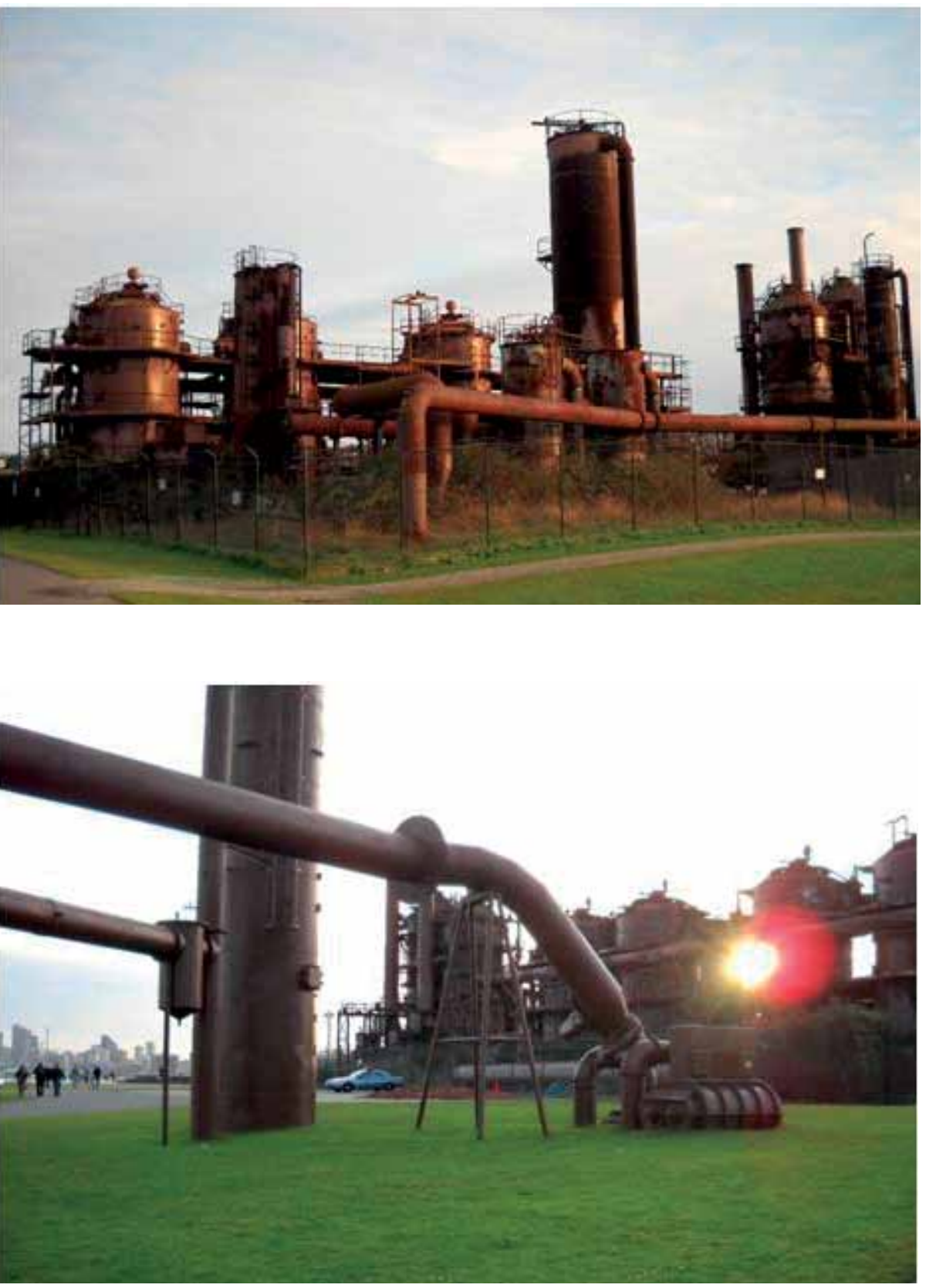

Gas Works Park in Seattle

Photo by the author 


\section{Plans for the gas works site: "a sacred core of iron structures and strong landform" 3}

In interviews, Haag has described being drawn to the towers of the plant, as other residents of the city apparently were. ${ }^{4} \mathrm{He}$ said he fell in love with the future park area and became determined to preserve at least some of the structures. Writers stress the aesthetic interest the structures held for him. For example, Randy Hester says "familiarity with the site led him to discover a sculptural beauty in the despised black pipes and towers. Haag recalls that the guardian spirit [the genius loci] of the place told him to leave the plant's ruins and build the park around them" (Hester 1983, 19-20). The University of Washington's research archive records that Haag's inspirations "literally came to him in a dream" and notes "he decided the structures should be saved-not for historical purposes, but rather, for purely aesthetic reasons, to provide an interesting visual anchor for the park design". ${ }^{5}$ Arthur Lubow (2004; emphasis added) writes "Haag appreciated the aesthetic merits of buildings that most observers dismissed as useless fossils." Haag told Michael Richard: "I haunted the buildings and let the spirit of the place enjoin me. I began seeing what I liked, then I liked what I saw-new eyes for old. Permanent oil slicks became plain without croppings of concrete, industrial middens were drumlins, the towers were ferro-forests and the brooding presence became the most sacred of symbols. I accepted these gifts, and decided to absolve the community's vindictive feel towards the gas plant" (Richard 1983, 15).

At the very start of the 1970s, when Richard Haag Associates was commissioned to design the park, Haag asked philosophy professor Frederick Adrian Siegler to accompany him to the gas works (as Haag noted, "I had a philosopher on my team"(Raymond 2008). Having climbed one of the towers and surveyed the landscape, Siegler enthusiastically endorsed Haag's ideas and encouraged Haag to invite visitors to tour the area. Haag recalls: "the philosopher told me that there was no way that I could take plans of this place down to City Hall and convince anyone that there was some worth, some value in these totemic iron structures, you know. And he was so right on. He said you should develop [an office on the site]" (Raymond 2008).

Haag cleaned up the on-site blacksmith shop and began using it as an office, a first step in re-purposing or changing the use of the existing structures. As Haag said, "we used that building as a demonstration of how you could take the sow's

\footnotetext{
3 A term included in Haag's Master Plan and quoted in Campbell (1973, 342).

4 As Way describes, "Haag saw the dramatic site for the first time by rowboat on an autumn night and was immediately drawn to the somber black towers of the gas plant, set on the promontory surrounded by water on three sides and the Olympic Mountains visible in the far distance" (Way 2015, 150).

5 Seehttps://web.archive.org/web/20051130053512/http://www.washington.edu/research/showcase/1958a.html.
} 

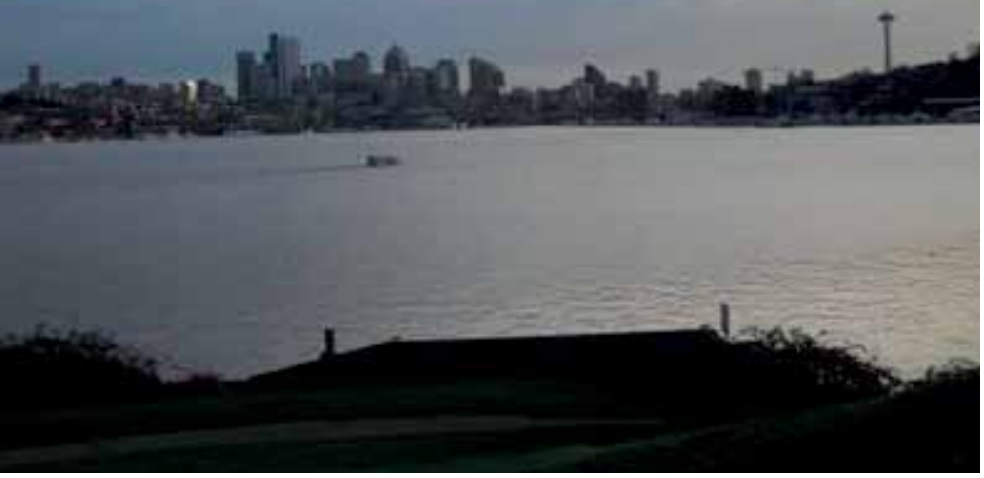

Gas Works Park in Seattle

Photo by the author

ear and convert it to a silk purse, if you will" (Raymond 2008)6. He himself stayed in the future park, moving around it, sleeping in some of the structures in his sleeping-bag. Over the next two years, he also worked on persuading city officials and members of the public to see what he saw in the gas works.

He set to work making the case for retention of the industrial ruins, encouraging the city to develop "new eyes for old." As Campbell puts it, "a tremendous public relations job had to be done to sell the concept of a park built around a trademark consisting of industrial relics which were generally considered 'eyesores,' even though their nature would be transformed by the treatment and activities of the area around them. In a very real sense, the plan envisioned 'recycling' of discarded and unusable industrial junk into something new and enjoyable-a metamorphosis of a unique order" (Campbell 1973, 342).

Haag gave presentations at public meetings and conducted tours for visitors to the site. Some of his supporters provided sketches of the future park. Writing in TheSeattle Times, Polly Lane (1971) reported that he intended for visitors to be "wooed by the magic of the huge, obsolete structures" and noted "Haag prefers to think of the area as a pleasure center rather than a park because the word park often brings to mind something he prefers this park not to be."

6 Glen Carter describes it as set "amid the bewildering array of iron" (1971). 
Haag also began drawing parallels between the structures and other artistic and architectural objects. Lane reports "Haag said the existing towers provide exciting sculpture without having to commission sculptors" (1971). He characterized the towers as "Iron Gothic" and compared objects at the gas-plant site with the 1970 Osaka Expo Pavilion as well as the works of such artists as Rube Goldberg, Jean Tinguely, and Mark Rothko.? Thaïsa Way says Haag had been planning this strategy over several years: "to present the structures and the site not merely as industrial artifacts or historical objects but as works of modern abstract art, a new type of art." $(2015,156)^{8}$

According to Campbell, Laurie Olin's sketches envision "rampant fun among the ruins" $(1973,342)$. In those sketches, reproduced at the end of Campbell's article, Olin writes, "think of this as an armature for the imagination... The functions are almost unlimited," and "we must cultivate the sense to leave things aroundthe right things and then not holler when they are put to new uses" $(1973,342)$. Campbell notes Haag's ideas for the remaining towers demonstrate "they were suitable for many new functions" $(1973,342)$. Likewise, Way writes, "[Victor] Steinbrueck, just as he had done for Pike Place Market, published sketches of how the park might be experienced as children and adults came to play within and on the towers, the machines, and in the landscape" (Way 2015, 159).

Haag encouraged all sorts of activities in the proposed park space. Olin's sketches included renderings of multiple uses of the park, with the towers presiding over the recreation. Way says Haag "was claiming that one could imagine anything

7 As Campbell $(1973,342)$ writes, "during his presentations Haag used a cleverly arranged series of slides, which alternated shots of modern sculpture (Tinguely, Smith, etc.) and architecture (Osaka Expo '7o structures) with shots taken of structures at the Gas Plant. The parallels were obvious, the humor was not lacking, and the point was conveyed. Most viewers understood immediately that much of what is accepted as 'art' today is no more appealing, visually, than the honest, weathered, 'iron gothic' Gas Plant structures."

8 Way describes aspects of Haag's persuasion campaign as follows: (Haag and photographer Mary Randlett photographed the site.) "This documentation gave Haag ammunition for a ... strategy, which he had been building over the past decade: to present the structures and the site not merely as industrial artifacts or historical objects, but as works of modern abstract art, a new type of art. Laurie Olin and Victor Steinbrueck sketched the site, suggesting new uses for and new ways of seeing the landscape and its history. Their drawings would be shared with public audiences as rough ideas for the site's possible development. Haag could also use the dramatic photographs to present the gasworks site to audiences not as a place of waste but as a new form of art. Haag elaborated on the potential of merging this artistic character with technological awe to create a new type of public space. He compared photographs of architectural structures with modern sculptures, abstract paintings, and modern art. He suggested that the 'generator towers offer a testimony to "Rube Goldberg" engineering and at the same time an "Iron Gothic" sculptural experience'... He compared the colors and textures of oil slicks to the works of Mark Rothko, the tower structures to the sculptures of Jean Tinguely. Slowly, the community began to consider how these ugly artifacts might be seen differently. They began to imagine not a toxic wasteland but a curated exhibit of modern sculpture and landscape. This significant reenvisioning of landscape came on the heels of a reappraisal of urban renewal and the emergence of the environmental movement... public meetings and presentations were critical to Haag's strategy for the park ... through multiple small meetings, he slowly opened the imaginations of residents, encouraging them to think of new ways of using the site" (Way 2015, 156, 158). 
Gas Works Park in Seattle

Photo by the author

in this park, as long as preserving the industrial past and its artifacts was part of the plan" (Way 2015, 155). ${ }^{9}$

Seattle's residents and city officials had much to say about these ideas for their new park. Many of their observations are recorded in articles and letters to the editor in The Seattle Times. We can clearly discern their assumptions about the aesthetic value of industrial structures as well as what a park should be in the controversy that ensued. Campbell argues that landscape architecture seldom

9 Way sees Haag's efforts as less collaborative than other writers have; she thinks Haag acted as an artist himself, persuading others of his own viewpoint, rather than soliciting and accepting their input: "first and foremost Haag's intention was to coax the public into seeing the potential of rethinking the possibilities of the site, essentially asking the public to develop new eyes for old.... However Haag's suggestion was not merely any new eyes or views or ideas about the park, but rather the strength of his eyes, view and ideas. Haag's process of persuasion was not one that invited community participation per se, as Randy Hester and others have claimed. Rather, Haag retained a foundational belief in the role of the landscape architect as the primary artist and designer. The intent of his public outreach was to persuade concerned individuals and groups that his design concept met the shared goal of a beautiful public park on the stunning location of the gas works location, but in a new language of post-industrial ruins. He did not design in response to the community, but rather he convinced them of the power of his design. And this design was based in the belief that the retention of the rusted industrial structures would be an asset, an artistic contribution to Seattle, and would serve to shape a new kind of urban public park" (Way 2013, 32-33). 
encountered such problems. 10 He says Haag's project is one that "did generate a full-blown, emotionally debated, front-page controversy centered on the philosophy of design governing a park master plan" (Campbell 1973, 339). Haag had fallen under the sway of the site's ruins, and was determined to create a new, imaginative park setting. But many people felt, and still feel, that industrial objects are not aesthetic objects, and that parks should offer the traditionally attractive and restful combinations of plants, views, and experiences of unspoiled nature (so far as that is possible) they have long provided. As Campbell points out, "a culture preconditioned to experience beauty only in the familiar-trees, grass, water, mountains, etc.- reacted with scorn and anger to the suggestion of hidden beauty in the rusted industrial forms already categorized and stored away in their subconscious as 'ugly"' $(1973,342)$.

In addition to being dismissed as ugly, the industrial ruins of the plant were called "grotesque," "monstrosities," and, often, "eyesores"; in a letter to the editor, W.H.H. (1971) pronounces: "let that confused minority who profess to see art in the structures go gaze raptly at an oil refinery." Neil L. Allen (1972) wrote the plant "was built for utilitarian purposes without any effort to make it beautiful" and would be a "memorial to all the rampant damage man has been inflicting upon his environment." Lindalee Edwards (1972), granddaughter of Myrtle Edwards, claimed Haag wanted to "fill the 20-acre site with many things unworthy of any park." (The city had intended to name the park after Myrtle Edwards, but this was eventually changed, as her family did not approve of the plan.) In one article, Haag muses over the possibility of burying the structures, leaving them to be discovered in some later decade by future archaeologists (Collins 1971). Letter writer W.H.H. suggested this was a better idea than the park plan on offer (W.H.H. 1971). Other observers saw no reason to preserve remnants of a plant that had belched toxins into the neighborhood for fifty years. Why remind the city of the price it paid for its gas production? This, they felt, would be like celebrating pollution and technological folly. Ned M. Thorne (1972) said "I can see a small-scale model of the gas plant, depicting it in its day of production, as a historical education museum exhibit, but a full-size gas tower left over as a park monument is not significant from a historical point of view, and it certainly is not a thing of beauty." According to Haag, a mayoral candidate promised the city he would raze the structures straightaway if elected to office (Raymond 2008). Even the editorial board

\footnotetext{
10 Campbell $(1973,339)$ claims "landscape architecture as a profession has been notably free of the sort of aesthetic controversies and debates afflicting other fields such as architecture, painting, and music; and the reasons, I suspect, are manifestly simple. The allied arts have passed through continual transitions of style and philosophy during the past century... Landscape architecture, by contrast, has evolved new details, most notably in the design of children's play areas, but has not passed through any genuine transitions in the philosophy of design. The same critical questions which have always posed themselves in site design are equally valid and current: 'Does the design respect the nature of the site? Does it respect the nature, wishes, and needs of the client and/or public? Does it possess aesthetic and functional integrity?' And since plant material in general possesses universal appeal, there has rarely been a controversy involving landscape architects which challenges their concept of beauty. After all, everybody loves a tree, right?”
} 
of The Seattle Times disagreed with Haag's plan, and argued "the decision-makers must choose a design concept that meets the test of public acceptance. Relatively few citizens would find retention of the so-called 'industrial sculptures' to their liking" (Seattle Times 1971).

But Haag did have supporters, including parks superintendent Hans A. Thompson and park board chairman Calhoun Dickinson, who said the towers "reminded him of an 'Emile Zola novel' with its depiction of an 'oppressive, industrial atmosphere" (Way 2015, 153-154). Val Varney (1971) reported Dickinson claimed the remnants "are heavy, metal sculptures that reflect an era. Once the park is complete people will see something in the towers." Gerald R. Anderson (1971) wrote "the gas-plant structures, which have been labeled hideous eyesores by some, have a remarkable beauty compared to much park sculpture for which great sums are spent. They are ours; why not just leave them there?" Lynne Harrison (1972) called the plan "imaginative" and said the towers are "a delight to the unprejudiced eye"; "there are, fortunately, many 'traditional' parks in Seattle. Surely there is room for an unusual, innovative, richly detailed urban park." According to Alf Collins (1972), "Mrs. Henry Gellert, widow of the Washington Natural Gas Co. executive who worked out details of the city's 10-year time purchase of the site, told the hearing that the plan would 'bring beauty out of blight which was my husband's concern."' The plan was described as refreshing, and Victor Steinbrueck pointed out "I see the structures as industrial engineering and they are very interesting and exciting" (Varney 1972). And in an intriguing letter, Keith Nissen (1971) claims "I find the gas plant fascinating, picturesque, eerie and at times positively sinister. Certain of the structures are hugely evocative and I have at least a few friends who share my feelings. I find it incredible anyone could describe them as boring."

The park plan also prompted reflection about what a park is, or should be. Curiously, Haag suggested, at least on a couple of occasions, that he was not really planning a park (though it seems clear the site is now readily classified as one, albeit an unusual one). Perhaps he had in mind the many normative assumptions about what a park is supposed to be, or perhaps he simply questioned the concept of a park. In an article in TheSeattle Times, John Voorhees raises the question of what, exactly, a park is, and what some poll respondents had to say about this. He writes:

What is a park?... what should a park be-particularly in this last part of the $20^{\text {th }}$ century and, hopefully, into the next one?... An unscientific, random poll last week turned up nearly as many opinions about what a park should be as there were persons asked. Yet there were certain similarities....It seems clear a composite "best park" would be restful, oriented toward nature, not overly organized, have plenty of space and be mostly off-limits to the automobile.... [No one polled was] turned on to saving any of the old gas plant on Lake Union. [Voorhees then criticizes Haag's contentions that the plant can remind us of what we do to our environments, and that the park could be a play area.]... Haag also stated that the park could become a national attraction...because of our interest in 
stopping pollution. If that line is pursued, then pulp mills, oil refineries and other polluters should already be outpulling Disneyland and Mount Rainier. (Voorhees 1971)

These ideas accord with many observers' convictions about parks, as well as the aims of landscape architecture. Board member John Andrew claimed the area "is a view park and we are leaving these monstrosities" (Varney 1972). Former Mayor Gordon S. Clinton complained "Myrtle Edwards Park was intended as just that-a park" (Robinson, n.d.). His words are aimed at establishing the future Gas Works Park was no park. Herb Robinson said "ideally, the city should wind up with a plan providing a certain amount of open space and a conventional setting for rest and relaxation, with special items of visitor interest" (Robinson, n.d.).

Yet, in 1972, following Haag's efforts and in the midst of lively debate, the City Council approved the plan. As work on the park commenced, Haag and his team launched ground-breaking measures to rehabilitate its soil. Some parts of the gas plant were removed, though the towers remained, and other structures have been repurposed and repainted for play and picnicking. A bibliography for Gas Works Park compiled by Richard Haag Associates notes of the year 1974: "derelict structures preserved for aesthetic, historic or adaptive use. Others selectively demolished" (Richard Haag Associates 2016). A significant portion of the park opened in 1975 .

Since that time, the park, and Haag, have won numerous accolades. Haag won the President's Award for Design Excellence from the American Society for Landscape Architecture. Gas Works Park achieved City of Seattle Historic/Landmark Status in 1999, was placed on Washington state's list of historic/landmark sites in 2002, and was added to the National Register of Historic Places in 2013. Many of the city's cherished events, such as its annual $4^{\text {th }}$ of July fireworks show, take place in or near the park. The ASLA jury wrote it is "a remarkably original and attractive example of how to reclaim a seemingly hopeless and obsolete industrial installation. Instead of being destroyed or disguised, it has been transformed into a lighthearted environment. A project of historical significance for the community" (quoted in Green 2015). This admiring appraisal was echoed in other publications. Lubow (2004) notes "the chimneys and compressors of the old plant now mirror the Seattle skyline like ruins of a previous civilization." The gas-plant structures have achieved historical importance, since they are among the very last in existence, and other landscape architects have looked to Haag's work as an example and inspiration. Numerous children have played over the years on the old machinery that provides a ready substitute for a jungle gym, and visitors fly kites on lawns carpeting once hopelessly contaminated ground. Stewards of the park intend to make new arguments in its favor by pursuing further historic status designations, such as national recognition as the first industrial landmark site and UNESCO world heritage status. Peter Kelley (2012) sounds a note of pride in observing "Gas Works 
and subsequent projects established Seattle as one of the first American cities willing to recast industrial sites into places to celebrate."

\section{3. "Bringing beauty out of blight"}

Haag's campaign to convince Seattle residents of the value of the gas-works ruins is remarkable for many reasons; I list only a few here. As noted above, it was the first major campaign to protect and preserve remnants of industrial heritage in a United States city park, and it also demonstrated, in a public forum, that industrial ruins can be regarded as aesthetic objects and can valuably contribute to park design. The campaign also exhibits practical but stimulating engagement with philosophical matters: it prompted impassioned community reflection, which at times veered into the philosophical, about just what a park should be, and the campaign, as well as responses to it, involved appeals to aesthetic judgment, concepts of beauty, and imagination (not to mention Haag receiving advice about strategy from a philosophy professor).

Now I assess the following outcomes of the plan and execution of the park: (1) the comparison Haag drew between artistic and architectural objects and the gas works structures, and (2) his encouragement of certain uses of these structures in the proposed park. Then (3) I briefly consider our concept, "park," and the assumptions about parks that became apparent during the conversations in Seattle, as well as how we should re-purpose abandoned, derelict, or post-industrial sites, such as the former gas plant.

(1)

As described above, Haag asked Seattle's residents to see the remaining gas works as aesthetically important and imaginatively engaging elements of the proposed park plan. When arguing that the oil slicks resembled Mark Rothko's work and the towers looked like Jean Tinguely's sculptures, Haag called attention to affinities between the form and materials of artistic objects and the gas-plant ruins and suggested the structures could be found sculptures; he asked Seattleites to extend wellestablished aesthetic categories to the gas-plant structures. He simply attempted to demonstrate that the industrial ruins belonged within those categories.

Haag is not alone in noting the aesthetic qualities industrial sites or objects may have. Le Corbusier and Walter Gropius made such observations-Le Corbusier (2007) in Toward an Architecture and Gropius (1980) in "The Development of Modern Industrial Architecture." Sigfried Giedion $(2009,167)$ describes "regions which seem far removed from aesthetic feeling," though they are not; they can have an aesthetic dimension. Elsewhere, he explicitly refers to the "unintentional beauty of American industrial architecture" (2009, 343; emphasis added). Giedion also notes that Julius Lessing, who was the first director of the Museum of Industrial 
Arts, said a display of American tools at the 1878 Paris World's Fair prompted him to experience an aesthetic reaction $(2009,340-341)$. Lessing even likened the tools to primitive instruments.

The famous photographs of Bernd and Hilla Becher provide perhaps the most obvious aesthetic counterpart to Haag's campaign on behalf of the gas-plant ruins. As is well-known, the Bechers photographed entire industrial landscapes as well as abandoned industrial objects such as water towers, and in doing so called attention to their subjects' formally appealing aspects. Their works - to name only a few: Water Towers, Industrial Façades, Industrial Landscapes, and Typologies of Industrial Buildings - reveal a fascination with industrial places and forms. ${ }^{11}$

In my view, Haag has drawn a successful analogy between the gas plant ruins and other products of human creativity; in fact, the connection is not very farfetched. His own well-chosen examples, and the additional ones noted above, illustrate that industrial objects can be and have been viewed aesthetically. The gas works do have formally appealing qualities, though that appeal could be obscured by the pollution they created. And as the structures are no longer actively functioning as gas works, their aesthetic attributes can emerge even more clearly within a park setting that frames them. It is worth noting, too, that some people are drawn to the aesthetic properties of the materials, such as metals and concrete, making up many of our built landscapes. These materials can serve both industrial and aesthetic purposes. For example, both metals and concrete are used in building various industrial and other structures, but they are also used in making jewelry. The towers could be appealing for people who simply admire the aesthetic impact of a mass of metal.

At the very least, the ruins of the gas plant can elicit a variety of sometimes extraordinarily complex aesthetic reactions. They can come to haunt our consciousness (based on what he has said, this appears to be what happened to Haag), and, as some of the letters (both supportive and disgusted) to The Seattle Times attest, can alternately be viewed as beautiful, picturesque, eerie, sublime, menacing, haunting, or, as many put it when they were abandoned (including Haag), ghostly. Jonathan Maskit proposes an apt new category-the interesting-to account for our reactions to places like the gas works. He describes what may happen when we regard post-industrial sites, and his description reflects the complexity of our reactions: "we find ourselves simultaneously awed and disgusted; impressed and depressed. The power of technological culture to transform nature is made manifest here in its starkest form. And yet, we do not turn away. We both rue what is no more and are smitten by what is" (Maskit 2007, 13-14).

11 Peter Reed mentions the work of the Bechers when describing Peter Latz's work on Landschaftspark Duisborg-Nord: "the industrial ruins [of Landschaftspark Duisborg-Nord], which could easily have been subjects for Bernd and Hilla Becher, who aestheticized German industrial culture in their photographs, have transcended their original rational function" (Reed 2005, 26). 
Some of these responses are in keeping with our reactions to other ruins from earlier centuries. As Elisabeth Clemence Chan writes:

Just as ancient ruins were enjoyed in the Classical gardens, industrial ruins are enjoyed for their mysterious and sublime qualities, as well as their melancholic (what many also call "gritty") qualities. Granted, what these places mean to people is difficult to discern, influence or even understand. To be sure, one person's mystery is another's gloom; one person's melancholy is another's creepiness; and one person's sublime prospect could be another's eyesore. It is fair to assume that every individual might have a different perception of industrial ruins based on their prior experience, interests, age, and countless other influences. (Chan 2009, 24)

The case can successfully be made, then, that the ruins do have aesthetic appeal (admittedly aesthetic appeal where one does not ordinarily expect to find it) and can instigate sometimes multi-faceted, indisputably aesthetic responses, ranging from perceptions of the alluring to the gritty, or both of these and others at the same time. As letter writer KeithNissen claimed, the gas-plant structures are quite fascinating and evocative. Not all industrial ruins are aesthetically compelling, though Haag was right to suggest these are. (If the towers were less striking, for whatever reason, our ability to see them as sculptural might be compromised.) As one would expect when it comes to aesthetic matters, some have agreed or been persuaded, then and now; some have not. Nevertheless, the arguments calling attention to the gas plant's aesthetic potential are certainly plausible.

One might claim that structures designed to fulfill a non-aesthetic function cannot have aesthetic appeal, though this is not a convincing objection. Many objects created for some other non-aesthetic use can aesthetically appeal to ussome kitchen utensils or office tools, for example. The fact that they are designed well to carry out their non-aesthetic function can itself be a source of aesthetic appeal. However, it seems clear that awareness of what the gas works really are did interfere with some people's ability to appreciate the aesthetic possibilities the structures represent, and I address this issue in the next section.

(2)

Even if he did this inadvertently, Haag encouraged the city's residents to not only view, but use, the structures as ruins. This has important implications for the debate about the nature of parks as well as for the problem of "memorializing" pollution.

Haag wished for people to observe the ruins' shapes, play among them, and generally treat them with the free-spirited exploration and enjoyment with which people have long interacted with ruins. As Campbell said, noted above, "their nature would be transformed by the treatment and activities of the area around them." Many of the features of traditional ruin-appreciation can be found here: treating formerly functioning built relics as aesthetic objects; focusing on their form following the lapse in their function; engaging with one's ruined surroundings in unconventional, playful, and 
perhaps creatively inspired ways, and, relating to this, sensing possibility in a change of function. It could be argued Haag used the space in this way himself, moving around it, sleeping in different places (even if he did this at least in part to gain familiarity with his work site). He also occupied the converted blacksmith shop in what Hester calls a "quasi-illegality [that] can be attractive to innovators": "[Haag] recalls the camaraderie his group experienced when they were ejected from their blacksmith-shop office by Seattle authorities during a storm" (Hester 1983, 21).

Now Haag and others suggested, at least on some occasions, that this made the park not really like a park at all, but instead, a pleasure area. Yet it is in parks and landscaped settings in particular that ruins have long been used and appreciated. This is actually a quite traditional feature of landscaping and park design; it has a long history. In prominently situating ruins within a park landscape and suggesting new uses for them, Gas Works Park falls within the tradition of planned landscapes and gardens strewn with ruins_- "follies"- that were so popular in earlier centuries. Usually, our park ruins are classical or romantic relics (or designed to look like them), not the remains of industry. But industrial ruins can be said to share the same appealing qualities as other kinds of park ruins. For example, it has been pointed out that Peter Latz had Bomarzo in mind when designing Landschaftspark Duisborg-Nord in Germany (Reed 2005, 26). As Chan writes:

It is my view that parks containing industrial ruins are designed and built because people enjoy ruins, especially in parks...

Ruins as used in Classical landscape design were part of the Picturesque aesthetic in which mystery, melancholy and the sublime were intrinsic. We see the same emotionally attractive aesthetic devices being used today, intentionally or not, in industrial ruin parks. One reason we tend to preserve and enjoy industrial ruins is that they have an emotional and aesthetic attractiveness to many people. As objectsin the landscape, relic architecture has long captured the imagination of artists, writers and designers....The attraction of ruins, whether ancient, recent, monumental, vernacularor industrial, reflects complex cultural aesthetics. This is demonstratedin the deep history of ruins used in landscape and garden design.... In today's industrial ruin parks, one could argue that ruins are being used as follies in much the same way they were used in eighteenth- and nineteenth-century Europe. Like the ruins at the Englishestate, Stowe, or the French garden Le Désert de Retz, rusting manufacturing structures built in the nineteenth and early twentieth centuries stand in some parks as aesthetic attractions and icons among rolling lawns, softened by garden plantings. (Chan 2009, 21, 23-24)

However, while industrial ruins may fit comfortably within the long tradition of ruins within landscaped settings, they do break from this tradition in one important way. They have previous functions that have been destructive to our landscapes. Even while one admires their beguiling aesthetic ambiguity, one may acknowledge that industrial objects have been put to destructive uses, and, as some Seattle residents pointed out, retaining the gas plant's remnants could remind us of this history. 
But if we conceive of the structures as traditional park ruins, we can resolve this tension. Ruins are elements of our built environment that are no longer functioning as they once did or no longer functioning at all. Industrial ruins are exceptionally good candidates for ruin-status, because it can be a relief to us that their functions are no longer active. We can quite literally call them follies-and be glad of this. And as Seattle's residents use the found sculptures of the gas plant in new ways, they make clear that polluting function is over, part of the past. Chan remarks "the park containing ruins appears cleaned and in a state of healing" (Chan 2009, 26). In my view, this is one reason for the "lighthearted" aspect of the park the ASLA jury recognized. The lightheartedness results at least in part from admiring and using the objects as aesthetically interesting or ruinous remnants while happily aware that their role in pollution is over. The structures have been transformed by their inclusion and new use in the changed landscape. They are now the ruins of industry, not its active instruments. Thus, we do not memorialize or celebrate pollution by retaining such structures in our parks. Instead, as we see the rusting hulks set among new grasses and see people playing and picnicking among what Haag termed the "sacred core of iron structures," we receive the optimistic impression that we are (at least one hopes) moving on from it, while retaining what is aesthetically interesting about the industrial past.

(3)

I would finally like to make some brief comments about our concepts of parks and park design, topics which obviously deserve more thorough consideration than I give them here.

As we have seen, Gas Works Park does not match the idea of the composite "best park" Voorhees's poll yielded. According to that view, parks should be serene and "natural," or perhaps should be kept that way (as we endeavor to do with many national United States parks), and this is partly why Haag's plan could be viewed as controversial. Gas Works Park is not a traditional park in that sense. It is a highly "unnatural" park environment, one in which human interference with nature is obvious (in many ways - for example, the gas plant's initial intrusion onto the shore of Lake Union and Haag's later modification of that plant).

Yet my claims above should make clear that in some respects, Gas Works Park is deeply traditional. First of all, it exhibits traditionally appreciated aesthetic qualities and prompts well-known aesthetic reactions. Second, as a park that prominently features ruins, it follows centuries of garden and landscape design. It may not even be out of step with the idea that a park should be close to nature. While its ruins themselves are not natural objects, their current presentation as ruins arguably shows respect for nature and a kind of return to nature, for, as I have attempted to show above, the park's aspect makes clear that the plant's destructive function is over (consider how Haag's description of the "ferro-forests" can bring 
nature to mind). For these reasons, the park is not as unconventional a park as we might initially suppose. Instead, it might be said to represent the next step in the evolution of ruins parks.

The concept of "park" encompasses both types of park-the composite "best park" idea (or what I will call the park as nature), certainly, but also the ruins park. Both belong to the history of park design.

But suppose one accepts that industrial ruins can be valuable elements in the design of a park. One could then argue that if we do decide to retain our industrial ruins, we should disturb them as little as possible. If we value industrial ruins, we should not clean or selectively prune them like plants, and then present them in a park environment along with modifications to other plants and landscaping. Why further conflate the natural and the artificial? Why not preserve nature in parks that are close to nature, and why not preserve industrial ruins in ruins parks? Why not suppose the more ruins remain at ruins sites, the better-leaving those ruins as close to their own "natural" state as possible?

This, to me, is an interesting possibility, and in some cases (perhaps when the ruins in question are especially aesthetically compelling or otherwise significant, or located in dense urban settings), it may be the right one. However, in the case of park design, it is probably often important to signal that an industrial site's function is no longer active. A clear change or shift in our perception of a site's function may have to occur; we may have to make it obvious that we are bringing beauty out of blight. Maskit describes a type of aesthetic engagement he calls renovation: "perhaps the best thing to do with such [post-industrial] sites (or at least with some of them), is to preserve their interesting character while turning them to new uses" (Maskit 2007, 14). This turn to new uses is an especially useful and valuable strategy for potential park sites that contain industrial ruins, for if they exhibit the process of renovation in some way, they are also likely to convey a shift or suspension in function. Haag accomplished this at Gas Works Park.

In my view, such a change works well for park settings in particular, even if this makes such parks more like works of art or artificial gardens than landscapes close to nature. There is room enough for different kinds of parks, as letter writer Lynne Harrison pointed out, and presenting industrial ruins in new ways in these settings is an especially positive and thought-provoking way of dealing with them. A change or shift toward new use is also likely to turn attention away from blight and toward the aesthetic potential of structures like the remaining gas works. In some cases, attention to aesthetic significance will serve us better than attention to historical significance. For example, we already feel remorse about the environmental cost of much of our recent technological history. Although we might admire the structures that carried out these technological tasks as feats of engineering (as Steinbrueck admired Seattle's gas-plant structures), unless these structures are somehow altered by their presentation or use, they can remind us of a history 
that we wish to put behind us. The details of a shift from blight to beauty must be addressed in more detail, and will probably vary widely from case to case..$^{2}$ But Gas Works Park provides a worthwhile example of this approach.

If we do not reconceive of certain industrial structures as ruins, and as potential new aesthetic objects, it is hard to ignore the impression that we would just be preserving instruments of pollution. Suppose Haag's plan had been to leave the gas plant as close as possible to the state it was in when it closed in the 1950 . The site itself would probably be intriguing for various reasons, as some people found it at the time, but it would not work especially well as a new park. In that case, a plan for a more conventional park, or a park as nature, along the shore of Lake Union might have been a better idea. Haag's plan is brilliant as much for what it mended and changed as much as for what it retained.

Our concept, "park," involves notions and traditions about which we can argue, as people in Seattle did in the early 1970s. As I have pointed out, the ideas about parks that surfaced during the debate in Seattle-the park as nature, and what I have described as the ruins park-both belong to its history. But there are other, more difficult dimensions to this concept: the degree to which the term "park" suggests human intervention, or ideally, non-intervention, in our landscapes, and whether and to what extent we should combine nature with human intervention. I can suggest at this point that interventions in abandoned, derelict, or postindustrial sites aimed at presenting industrial structures as ruins, and bringing beauty out of blight, are positive interventions, even (or, perhaps, especially) if they may be complex hybrids of the natural and the artificial. The popular High Line in Manhattan is a fine current example. And in their hybrid aspect, these parks resemble many ruins in general-combinations of human-constructed relics and nature, reasserting itself. Perhaps this can also serve as an optimistic projected description of not only some parks, but many more scenes of the $21^{\text {st }}$ century that Voorhees asked us to envision.

\section{In closing: celebrating the follies and ferro-forests of our future}

In 2008, Richard Haag described paying a visit to his inspired and inspiring creation:

The park is purposely designed as a very open, spontaneous park. And so you find all kinds of activities happening. Just a moment ago there was a man playing a harp down here, and I heard some bongos earlier, and a kite was flying just off the hill, the kite hill behind me. And it's a park where you got such an exhilarating sense of openness, of light and air and space and the most incredible view of downtown Seattle, repeated

12 Not to put too fine a point on it, but we must take the sow's ear in question and successfully convert it to a silk purse, to use Haag's phrase. 
and reflected in the lake. But imagine this site without these structures: just ballfields or just, you know, your usual athletic kind of feel. It'd be a nowhere place. (Raymond 2008)

Haag's words emphasize the park's unique sense of place-light, view, space, Lake Union, downtown Seattle. They also emphasize all those activities Haag hoped forpeople playing music, flying kites. This is nothing like a "nowhere place." Haag then asks us to imagine the site without the structures, and indeed, after all he has asked Seattle's residents to imagine before, this request is a dispiriting one. This place would be different, and hardly better, without the relics of the gas works. It would be-paradoxically enough, in a place containing remnants of industryless alive.

The gas plant should probably never have been built where it was. One could argue it should never have been built at all. But this did happen, where it happened. And when the time came to decide how to address the equipment that had thankfully rumbled to a stop, Haag, I have tried to show, made the most of the opportunity.

Haag's achievements give us much to think about as we consider plans for our other abandoned, derelict, or post-industrial sites. He has provided a successful model for the practice of retaining industrial ruins within parks without thereby promoting our memories or practices of environmental degradation. And this is because, as I have argued, the structures appear as ruins at the transformed edge of Lake Union. I have claimed that what may look new about Gas Works Park is actually somewhat traditional, and recalls our centuries-long interest in ruins in general. Ruins represent a link between our pasts and our futures, between former functions and whatever new ones we may envision. As the follies of our industrial era-as ruins-industrial fragments like those in Gas Works Park are perhaps best suited to bring beauty out of blight, to signal that one era has ended and another has begun. Bridging these eras are traces of former industry that are redeemed by their aesthetically arresting qualities. As Olin said, their functions can be unlimited; they, and the parks in which we find them, can be an armature for our imaginations. This is something to celebrate.

\section{References:}

Allen, Neil L. 1972. The Seattle Times, February 27.

Anderson, Gerald R. 1971. The Seattle Times, July 19

Campbell, Craig. July 1973. "Seattle's Gas Plant Park." Landscape Architecture: 338—42.

Carter, Glen. 1971. "Surfside Six: just junk." The Seattle Times, January 8

Chan, Elisabeth Clemence. 2009. "What roles for ruins? Meaning and narrative of industrial ruins in contemporary parks." Journal of Landscape Architecture 4: 20-31. 


\section{Tanya Whitehouse}

Collins, Alf. 1971. "Consultant finds little can grow in most of gas-plant park site." The Seattle Times, July 18

Collins, Alf. 1972. "Edwards Park plan wins support." The Seattle Times, March 2.

Dorpat, Paul. 2006. "Stonehenge in Seattle." The Seattle Times, November 26. http://community.seattletimes. nwsource.com/archive/?date=20061126\&slug=pacificpdorp26.

Easton, Valerie. 2015. "Meet Richard Haag: The landscape architect has designed many of our area's best-known spaces." TheSeattle Times Pacific NW Magazine, June 19. http://www.seattletimes. com/pacific-nw-magazine/meet-richard-haag-the-landscape-architect-has-designed-many-ofour-areas-best-known-spaces/.

Edwards, Lindalee. 1972. "'Eyesores' don't belong in Myrtle Edwards Park." The Seattle Times, March 1.

Giedion, Sigfried. 2009. Space, Time and Architecture: The Growth of a New Tradition. Cambridge: Harvard University Press.

Green, Jared. 2015. "Seattle Layers Nature and Infrastructure (Part 1)." The Dirt: Uniting the Built and Natural Environments (American Society of Landscape Architects), May 7. https://dirt.asla org/2015/05/07/seattle-layers-nature-and-infrastructure-part-1-2/.

Gropius, Walter. 1980. "The Development of Modern Industrial Architecture." In Form and Function: A Source Book for the History of Architecture and Design 1890 — 1939, edited by Tim Benton, Charlotte Benton, and Dennis Sharp, 53 - 55. Granada: Open University Press.

Harrison, Lynne. 1972. The Seattle Times, January 4.

Hester, Randy. 1983. "Labors of Love in the Public Landscape." Places 1: 18 —27.

Kelley, Peter. 2012. "New exhibit celebrates parks, public spaces reclaimed from unusual uses - with slide show." UW Today, May 11. http://www.washington.edu/news/2012/05/11/new-exhibit-celebrates-parks-public-spaces-reclaimed-from-unusual-uses-with-slide-show/.

Lane, Polly. 1971. "Gas-plant towers get reprieve in plan." The Seattle Times, December 12.

Le Corbusier. 2007. Toward an Architecture. Translated by John Goodman. Los Angeles: Getty Research Institute.

Lubow, Arthur. 2004. "The Anti-Olmsted." The New York Times, May 16. http://www.nytimes. com/2004/05/16/magazine/the-anti-olmsted.html? _ r=0

Maskit, Jonathan. 2007. "'Line of Wreckage': Towards a Post-Industrial Environmental Aesthetics." Ethics, Place, \& Environment 10: 323-37.

Nissen Keith. 1971. The Seattle Times, August 1.

Raymond, Vaun. 2008. "Interview with Richard Haag (interviewed at Gas Works Park, October 9, 2008)." Lake Union Virtual Museum. http://www.lakeunionhistory.org/Oral_History,_Gasworks_Park. html.

Reed, Peter. 2005. Groundswell: Constructing the Contemporary Landscape. New York: The Museum of Modern Art.

Richard Haag Associates. 2016. "Gas Works Park Partial Bibliography." http://richhaagassoc.com/studio/wp-content/uploads/2013/05/GWP_HistoryBibliographyAwards.pdf.

Richard, Michael. 1983. Seattle's Gas Works Park: The History, the Designer, the Plant, the Park, Map \& Tour. Seattle: Tilikum Place Printers. 
Robinson, Herb. n.d. "A reminder of 'environmental abuse'? Gas-plant relics involve economics, too." The Seattle Times.

Seattle Times. 1971. Editorial. The Seattle Times, December 27.

Thorne, Ned M. 1972. The Seattle Times, January 21.

Varney, Val. 1971. "Decision near an old gas plant." The Seattle Times, December 17.

Varney, Val. 1972. "Edwards Park towers to remain." The Seattle Times, January 7.

Voorhees, John. 1971. "A park is a park is a park." The Seattle Times, July 25.

W.H.H. 1971. Letter to the editor. The Seattle Times, July 23.

"Interview with Thaïsa Way on 10 Parks That Changed America." n.d. American Society of Landscape Architects. https://www.asla.org/ContentDetail.aspx?id=48144.

Way, Thaïsa. 2013. "Landscapes of industrial excess: A thick sections approach to Gas Works Park." Journal of Landscape Architecture 8: 28-39.

Way, Thaïsa. 2015. The Landscape Architecture of Richard Haag: From Modern Space to Urban Ecological Design. Seattle: University of Washington Press.

Welch, Ruth. 1972. Letter to the editor. The Seattle Times, January 16. 